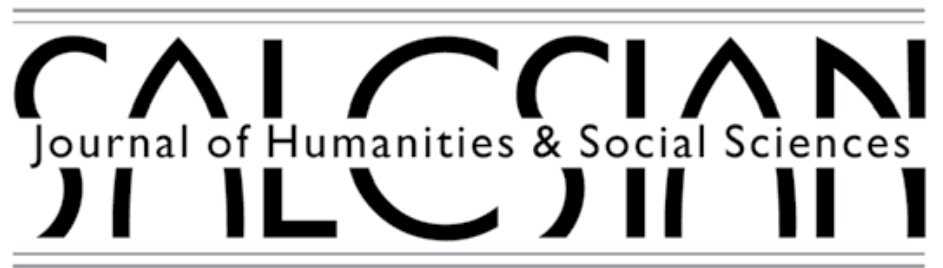

Vol. X, No. 2

December 2019

\title{
REMEMBERING GANDHI:
}

\section{POLITICAL PHILOSOPHER AND SOCIAL THEORIST}

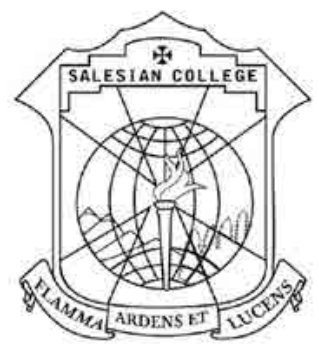

Published by

Salesian College Publication

Sonada - Darjeeling - 734209

Phone: (+91) 8918985019

www.salesiancollege.ac.in

www.publications.salesiancollege.net
Don Bosco Road, Siliguri

734001 / Post Box No. 73

principal@salesiancollege.net salesian.publication@gmail.com 
"My belief is that whenever you go into somebody's head anyone's head - it's all insecurity.... I live with that fear that in a minute everything could go away."

Andre Acimann, in the interniew on his books - Call me by Your name and Find $M e$, in Rich Juzwiak, "The Story Continues, after all" Times, November, 4, 2019, 91. 


\section{REMEMBERING GANDHI: \\ POLITICAL PHILOSOPHER AND SOCIAL THEORIST}

\begin{tabular}{lll}
\hline ISSN 0976-1861 & December 2019 & Vol. X, No.2 \\
\hline
\end{tabular}

\section{CONTENTS}

\section{Editorial}

Remembering Mahatma as Gandhi:

Gandhi as Political Philosopher and Social Theorist

\section{Original Articles}

Gandhi and the Development Discourse

Siby K. George

A Conciliatory Gaze:

SNG on MK Gandhi and BR Ambedkar

George Thadathil

Gandhi's Legacy: Vandana Shiva as Gandhi's Heir

Pius V Thomas and Violina Patowary

Gandhi in the Tropics: Climate, Disease and Medicine

Bikash Sarma

The Violence of Non-violence:

Reading Nirad C Chaudhuri Rereading Gandhi

Jaydeep Chakrabarty

Freedom, Authority and Care as Moral Postulates:

Reexamining Gandhi's Proposal for Ethical Reconstruction

Subhra Nag

Decoding Gandhigiri: A Genealogy of a 'popular' Gandhi Abhijit Ray 
Salesian Journal of Humanities and Social Sciences, Vol. X, No. 2 (Dec 2019) ISSN: 0976-1861

Section: Contents

\section{General Commentaries}

Labour for Love or Love for Labour?

Shruti Sharma

Production of a 'degenerate' form

Vasudeva K. Naidu

\section{Book Reviews}

Irfan Ahmad, Religion as Critique:

Islamic Critical Thinking from Mecca to Marketplace

By Shofiul Alom Pathan

Punam Tripathi, The Vulnerable Andaman and Nicobar Islands:

A study of Disasters and Response

By Bipul Chhetri

Sreetanwi Chakraborty, The Sleeping Beauty Wakes Up

By Monika Rana

Our Contributors

Notes to Contributors 